\title{
The $\alpha_{2} \delta$ Subunit and Absence Epilepsy: Beyond Calcium Channels?
}

\author{
Roberta Celli ${ }^{1, \S}$, Ines Santolini ${ }^{1, \S}$, Michela Guiducci ${ }^{2}$, Gilles van Luijtelaar ${ }^{3}$, Pasquale Parisi $^{2}$, \\ Pasquale Striano ${ }^{4}$, Roberto Gradini ${ }^{1,5}$, Giuseppe Battaglia ${ }^{1}$, Richard T. Ngomba ${ }^{6}$ and \\ Ferdinando Nicoletti ${ }^{1,7, *}$
}

${ }^{1}$ I.R.C.C.S. Neuromed, Neuropharmacology Unit, Pozzilli, (IS), Italy; Departments of ${ }^{2}$ Neurosciences, Mental Health and Sensory Organs, ${ }^{5}$ Experimental Medicine, and ${ }^{7}$ Physiology and Pharmacology, University Sapienza, Rome, Italy; ${ }^{3}$ Donders Centre for Cognition, Donders Institute for Brain, Cognition and Behaviour, Radboud University, Nijmegen, The Netherlands; ${ }^{4}$ Pediatric Neurology and Muscular Diseases Unit, Department of Neurosciences, Rehabilitation, Ophthalmology, Genetics, Maternal and Child Health, University of Genoa, "G. Gaslini" Institute, Genova, Italy; ${ }^{6}$ University of Lincoln, School of Pharmacy, Lincoln, United Kingdom

\section{A R T I C L E H IS T O R Y \\ Received: November 23, 2016 \\ Revised: January 16, 2017 \\ Accepted: March 06, 2017 \\ DOI: \\ $10.2174 / 1570159 X 1566617030910545$}

\begin{abstract}
Background: Spike-wave discharges, underlying absence seizures, are generated within a cortico-thalamo-cortical network that involves the somatosensory cortex, the reticular thalamic nucleus, and the ventrobasal thalamic nuclei. Activation of T-type voltage-sensitive calcium channels (VSCCs) contributes to the pathological oscillatory activity of this network, and some of the first-line drugs used in the treatment of absence epilepsy inhibit T-type calcium channels. The $\alpha_{2} \delta$ subunit is a component of high voltage-activated VSCCs (i.e., L-, N-, P/Q-, and R channels) and studies carried out in heterologous expression systems suggest that it may also associate with T channels. The $\alpha_{2} \delta$ subunit is also targeted by thrombospondins, which regulate synaptogenesis in the central nervous system.
\end{abstract}

Objective: To discuss the potential role for the thrombospondin $/ \alpha_{2} \delta$ axis in the pathophysiology of absence epilepsy.

Methods: We searched PubMed articles for the terms "absence epilepsy", "T-type voltage-sensitive calcium channels", “ $\alpha_{2} \delta$ subunit", "ducky mice", "pregabalin”, "gabapentin”, "thrombospondins", and included papers focusing this Review's scope.

Results: We moved from the evidence that mice lacking the $\alpha_{2} \delta-2$ subunit show absence seizures and $\alpha_{2} \delta$ ligands (gabapentin and pregabalin) are detrimental in the treatment of absence epilepsy. This suggests that $\alpha_{2} \delta$ may be protective against absence epilepsy via a mechanism that does not involve $T$ channels. We discuss the interaction between thrombospondins and $\alpha_{2} \delta$ and its potential relevance in the regulation of excitatory synaptic formation in the cortico-thalamo-cortical network.

Conclusion: We speculate on the possibility that the thrombospondin $/ \alpha_{2} \delta$ axis is critical for the correct functioning of the cortico-thalamo-cortical network, and that abnormalities in this axis may play a role in the pathophysiology of absence epilepsy.

Keywords: $\alpha_{2} \delta$ subunit, T-type voltage-sensitive $\mathrm{Ca}^{2+}$ channels, non-T-type voltage-sensitive $\mathrm{Ca}^{2+}$ channels, ducky mice, pregabalin, gabapentin, absence epilepsy, thrombospondins.

\section{T-TYPE VOLTAGE-SENSITIVE CALCIUM CHANNELS: THE KEY MOLECULAR PLAYERS IN ABSENCE EPILEPSY}

Absence epilepsy is the most common form of pediatric epilepsy, with an estimated annual incidence of 1-8 per 100,000 children aged 4-15 years, and accounting for 10-

\footnotetext{
*Address correspondence to this author at the Department of Physiology and Pharmacology, University Sapienza, Piazzale Aldo Moro, 5, 00185 Rome, Italy; Tel: +390865 915211; Fax: +390865 927575;

E-mail: ferdinandonicoletti@hotmail.com

${ }^{\S}$ Co-first Authors
}

$17 \%$ of all cases of childhood-onset epilepsy [1]. Chilhood and juvenile absence epilepsy belongs to a group of epileptic syndromes of genetic origin classified as "idiopathic generalyzed epilepsies" (IGEs) by the International League Against Epilepsy [2]. Absence seizures, the hallmark of absence epilepsy, are characterized by transient lapses of consciousness associated with bilateral, symmetrical and generalized spike-wave discharges (SWDs) at the electroencephalogram (EEG), generated by pathological oscillations in a cortico-thalamo-cortical network with a cortical origin. This SWDs generating network includes interconnected pyramidal cells and GABAergic interneurons in the somatosensory cortex (SSCtx), thalamocortical relay 
cells in the ventrobasal (VB) thalamic nuclei, the reticular thalamic nucleus (nRT), and their connecting pathways [3-6] (Fig. 1). Highly excitable cells in deep layers of the SSCtx send excitatory fibers to both the VB thalamic nuclei and nRT. VB neurons, in turn, send excitatory fibers to the cortical pyramidal neurons and to GABAergic nRT neurons, which are interconnected by gap junctions. nRT GABAergic neurons send their axons to VB thalamic nuclei, but not to the SSCtx. The activity of nRT neurons is regulated by $\mathrm{GABA}_{\mathrm{A}}$ receptors targeted by the antiabsence drug, clonazepam [3, 7-10] (Fig. 1). Genetic models of absence epilepsy include tottering, leaner, roller and rocker mice carrying mutations in the gene encoding for the $\alpha_{1}$ subunit of $\mathrm{P} / \mathrm{Q}-$ type voltage-sensitive calcium channels (VSCCs), stargazer mice lacking the protein stargazin, lethargic and ducky mice carrying mutations in the genes encoding the $\beta_{4}$ and $\alpha_{2} \delta$ subunits of VSCCs, respectively [9], and Genetic Absence Epilepsy Rats from Strasbourg (GAERS) and Wistar Albino Glaxo/Rijswijk (WAG/Rij) rats, which develop spontaneous absence seizures with age [6].

Activation of T-type VSCCs contributes to the generation of pathological oscillations underlying SWDs. These channels are activated at negative membrane potentials and show a fast voltage-dependent inactivation with respect to other VSCCs. Owing to these peculiar functional properties, $\mathrm{T}$ channels are involved in the generation of repetitive firing in the cortico-thalamo-cortical network $[11,12]$. In the

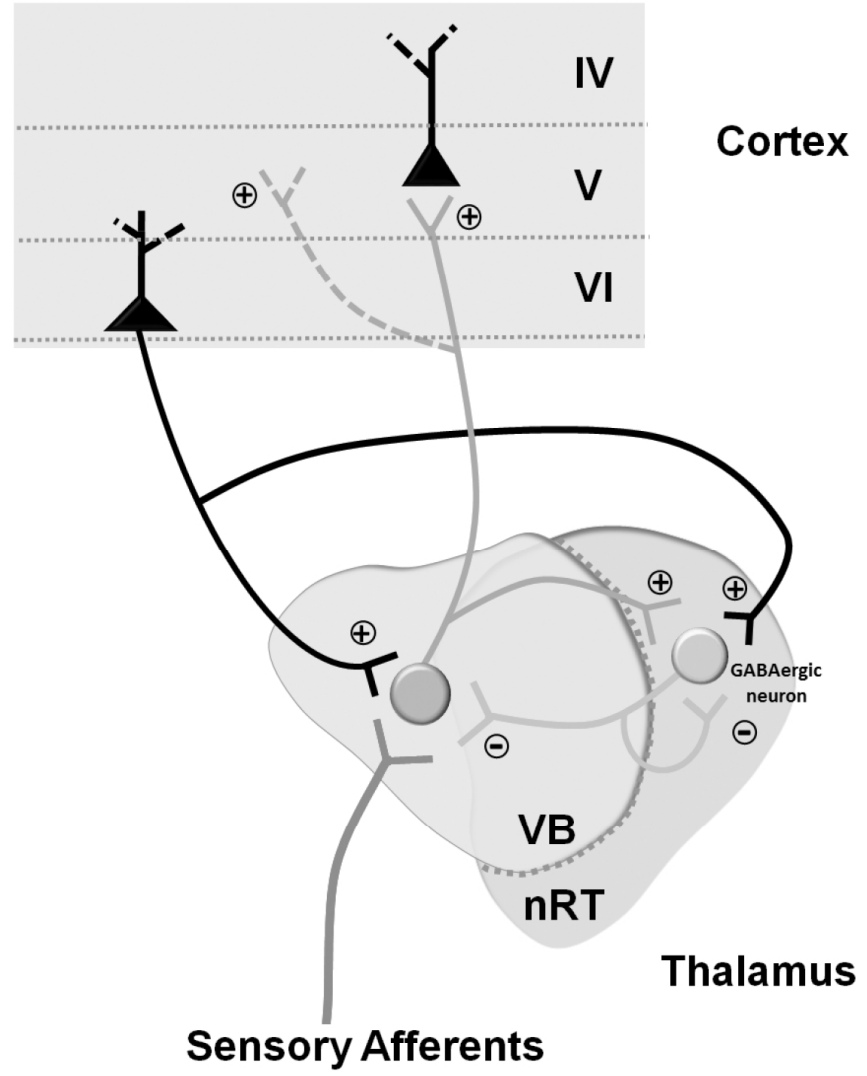

Fig. (1). Cortico-thalamo-cortical network underlying absence seizures. $\mathrm{VB}=$ Ventrobasal thalamic nuclei; $\mathrm{nRT}=$ reticular thalamic nucleus. GABAergic neurons projecting from the $\mathrm{nRT}$ to the $\mathrm{VB}$. pathophysiology of SWDs, an increased excitatory drive from the SSCtx to the nRT generates pathological bursts of nRT GABAergic neurons leading to $\mathrm{GABA}_{B}$ receptormediated inhibitory postsynaptic potentials (IPSPs) in VB thalamic neurons. The resulting hyperpolarization enhances the activity of T-type VSCCs in VB thalamic neurons producing the pathological $3-4 \mathrm{~Hz}$ oscillations that are typical of absence seizures in humans and $7-11 \mathrm{~Hz}$ in the genetic rat models [3]. Based on pioneering in vitro studies, it is thought that the therapeutic activity of ethosuximide in absence epilepsy occurs via the inhibition of low-threshold $\mathrm{Ca}^{2+}$ current $\left(\mathrm{I}_{\mathrm{T}}\right)$ in the thalamus and SSCtx [13-15].

There are three subtypes of T-type calcium channels: $\mathrm{Ca}_{\mathrm{V}} 3.1, \mathrm{Ca}_{\mathrm{v}} 3.2$ and $\mathrm{Ca}_{\mathrm{v}} 3.3$, containing the pore-forming $\alpha_{1} \mathrm{G}, \alpha_{1} \mathrm{H}$ and $\alpha_{1} \mathrm{I}$ subunits, respectively [16]. $\mathrm{Ca}_{2} 3.2$ and $\mathrm{Ca}_{\mathrm{V}} 3.3$ channels are expressed in nRT neurons and at least $\mathrm{Ca}_{\mathrm{V}} 3.3$ has been implicated in the generation of nRT bursts. $\mathrm{Ca}_{\mathrm{V}} 3.1$ channels are highly expressed in thalamocortical neurons, and all types of $\mathrm{T}$ channels are found in cortical neurons [17-19]. Studies carried out in WAG/Rij rats support the role of $\mathrm{T}$ channels in the pathophysiology of absence epilepsy. Changes in the transcript and protein levels of $\mathrm{Ca}_{\vee} 3.1$ have been found in thalamic nuclei of presymptomatic WAG/Rij rats, and $\mathrm{I}_{\mathrm{T}}$ current density was increased in thalamic neurons of WAG/Rij rats as compared to agematched non epileptic controls [20,21].

\section{ROLE FOR THE $\alpha_{2} \delta$ SUBUNIT IN THE MODULATION OF VSCCs}

VSCCs are formed by a multimolecular complex that includes the $\alpha_{1}, \beta_{1}, \gamma$, and $\alpha_{2} \delta$ subunits [22]. The $\alpha_{1}$ subunit forms the ion channel and accounts for the basic properties of the channel. Based on the specific type of the $\alpha_{1}$ subunit, VSCCs are classified into T-type (containing the $\alpha_{1} \mathrm{G}, \alpha_{1} \mathrm{H}$ and $\alpha_{1} \mathrm{I}$ subunits), L-type (containing the $\alpha_{1} \mathrm{C}, \alpha_{1} \mathrm{D}, \alpha_{1} \mathrm{~S}$, and $\alpha_{1} \mathrm{~F}$ subunits), $\mathrm{P} / \mathrm{Q}$-type (containing the $\alpha_{1} \mathrm{~A}$ subunit), $\mathrm{N}$-type (containing the $\alpha_{1} \mathrm{~B}$ subunit), and R-type (containing the $\alpha_{1} \mathrm{E}$ subunit) [16]. There are four isoforms of the intracellular $\beta$ subunit, and eight isoforms of the transmembrane $\gamma$ subunits, which do not confer a particular specificity to the VSCCs, although the $\gamma$ subunit is preferentially found in L-type channels of the skeletal muscle [23, 24]. The $\gamma_{2}$ subunit belongs to the group of transmembrane AMPA-receptor regulating proteins (TARPs) and is also named stargazin [25, 26]. Interestingly, stargazer mice lacking the $\gamma_{2}$ subunit show a severe neurological phenotype characterized by ataxia and absence epilepsy [27-30]. Stargazin levels are altered in the SSCtx of GAERS, but not in the cortex of WAG/Rij rats [31].

The transmembrane $\alpha_{2} \delta$ subunit is formed by the $\alpha_{2}$ and $\delta$ subunits covalently linked by a disulfide bridge. Interestingly, the two subunits are generated by a single gene product, which is post-translationally cleaved. The $\alpha_{2}$ subunit is glycosylated and interacts extracellularly with the $\alpha_{1}$ subunit. The $\delta$ subunit has a single transmembrane domain and interacts with anchoring intracellular proteins via the C-terminal region [32]. There are four isoforms of the $\alpha_{2} \delta$ subunit, produced by different genes. $\alpha_{2} \delta-1$, originally described in the skeletal muscle, is ubiquitous; $\alpha_{2} \delta-2$ and $\alpha_{2} \delta-3$ are specifically found in neurons, whereas $\alpha_{2} \delta-4$ is non-neuronal. 
The $\alpha_{2} \delta-1$ protein is mainly present in axon terminals of excitatory neurons [33], whereas the $\alpha_{2} \delta-2$ protein is expressed by cerebellar Purkinje cells [34]. The $\alpha_{2} \delta$-3 protein is ubiquitously expressed in the forebrain [33].

The $\alpha_{2} \delta$ subunit regulates the activity of VSCCs by increasing current amplitude and causing a shift of voltagedependent activation towards more hyperpolarized membrane potentials [35-39]. In addition, the $\alpha_{2} \delta$ subunit regulates cellular trafficking and membrane expression of VSCCs. Accordingly, transient expression of the $\alpha_{2} \delta-1,-2$, and -3 subunits in cultured hippocampal neurons targets $\mathrm{P} / \mathrm{Q}$ channels in presynaptic terminals, thereby enhancing depolarizationevoked neurotransmitter release [40]. This mechanism may be particularly relevant under pathological conditions, as suggested by the evidence that the $\alpha_{2} \delta-1$ subunit translocates from neuronal cell bodies of dorsal root ganglia to axon terminals in the superficial layers of the dorsal horns of the spinal cord in a mouse model of neuropathic pain [41].

\section{THE AMBIGUOUS ROLE FOR THE $\alpha_{2} \delta$ SUBUNIT IN ABSENCE EPILEPSY}

\subsection{Studies on the Association Between the $\alpha_{2} \delta$ Subunit with $\mathbf{T}$ Channels in Heterologous Expression Systems}

It is unclear to date whether native $\mathrm{T}$ channels associate with the $\alpha_{2} \delta$ subunit. All available studies were generated in heterologous expression systems and existing data are controversial. Overexpression of $\alpha_{2} \delta$ in NG108 cells influences the voltage-dependence of activation of T-type calcium channels although the presence of endogenous high voltage-activated (HVA) channels in these cells is a confounding factor [42]. Using transfected monkey COS-7 cells and Xenopus oocytes co-expressing $\alpha_{2} \delta$ and $\alpha_{1} \mathrm{G}$ subunits the same authors found that the $\alpha_{2} \delta$ subunit enhances membrane insertion or stabilization of $\mathrm{Ca}_{\mathrm{v}} 3.1 \mathrm{~T}$ channels without changing the voltage-dependence or kinetics of $\mathrm{Ca}^{2+}$ currents [43], as opposed to data obtained in NG108 cells [42]. A potential role for the $\alpha_{2} \delta$ subunit in the regulation of membrane insertion of $\mathrm{T}$ channels was also suggested by the use of GFP-tagged $\mathrm{Ca}_{\mathrm{v}} 3.2$ channels in various expression systems [44], and by co-immunoprecipitation in osteocyte membranes [45]. Contrasting findings were obtained in transfected HEK293 cells, where the same authors reported either no or small effects of the $\alpha_{2} \delta$ subunit on voltagedependence or inactivation kinetics of $\mathrm{T}$ channel [46-48]. These findings raise the possibility that $\alpha_{2} \delta$ may associate with, and facilitate the activation of, $\mathrm{T}$ channels in neurons. However, this remains to be determined taking into account that HVA channels expressed in neurons may compete with $\mathrm{T}$ channels for the interaction with the $\alpha_{2} \delta$ subunit.

\subsection{The Ducky Mouse: An Intriguing Example of Absence Epilepy Associated with the Lack of $\alpha_{2} \delta$ Subunit}

The association between the Cacna2d2 gene and childhood absence epilepsy suggests a role for the $\alpha_{2} \delta$ subunit in the pathophysiology of absence seizures [49]. Because the $\alpha_{2} \delta$ subunit facilitates the activity of T channels (see above) it is reasonable to predict that the lack of the $\alpha_{2} \delta$ subunit confers protection against absence seizures. In contrast, ducky mice, characterized by a spontaneous loss-of- function mutation of the Cacna2d2 gene, show generalized bilateral SWDs with a frequency of $5-7 \mathrm{~Hz}$, and are considered as a genetic model for absence epilepsy [34]. Ducky mice also show severe ataxia, dyskinesias, dysgenesis of the cerebellum and other central nervous system (CNS) regions, axonal dystrophy and demyelination [50]. Another spontaneous mutation of the Cacna $2 d 2$ gene (entla) encodes a mutant form of the $\alpha_{2} \delta$-2 protein with an intact C-terminus. This mutation also causes an atypical form of generalized absence epilepsy in mice [51], as does a targeted knockout of Cacna $2 d 2$ [52]. The epileptic phenotype of mice lacking $\alpha_{2} \delta$ 2 is counterintuitive if one hypothesizes that the $\alpha_{2} \delta$ subunit positively modulates $\mathrm{T}$-type calcium channels in neurons. However, we cannot exclude that $\alpha_{2} \delta-2$ and $\mathrm{T}$ channels are not expressed in the same neuronal compartments and that the lack of $\alpha_{2} \delta-2$ in ducky mice causes absence seizures through mechanisms that do not involve T channels, e.g., via functional abnormalities of HVA VSCCs.

\subsection{Lack of Therapeutic Activity of the two $\alpha_{2} \delta$ Ligands, Gabapentin and Pregabalin, in Absence Epilepsy}

Gabapentin and pregabalin have been developed for the treatment of focal epilepsy and are currently used in the treatment of neuropathic pain, migraine, anxiety disorders, and bipolar disorders [53, 54]. Gabapentin and pregabalin bind selectively to $\alpha_{2} \delta-1$ and $\alpha_{2} \delta-2$ with nanomolar affinity [55-58]. An arginine residue in position 217 of $\alpha_{2} \delta-1$ is part of the binding pocket, and binding of both $\left[{ }^{3} \mathrm{H}\right]$ gabapentin and $\left[{ }^{3} \mathrm{H}\right]$ pregabalin is largely reduced in the brain regions of transgenic mice with the $\alpha_{2} \delta-1 \mathrm{R} 217 \mathrm{~A}$ mutation $[38,59-62]$. Interaction of gabapentin and pregabalin with $\alpha_{2} \delta$ has two major effect on VSCCs: (i) a reduced membrane localization of $\alpha_{2} \delta$ and $\alpha_{1}$ subunits; and (ii) a reduced calcium channel current. It is generally believed that both effects contribute to the therapeutic action of gabapentin and pregabalin in focal epilepsy, neuropathic pain, and generalyzed anxiety disorder $[61,63]$.

By interacting with the $\alpha_{2} \delta$ subunit, gabapentin and pregabalin are expected to have therapeutic potential in absence epilepsy as a result of $\mathrm{T}$ channel inhibition. In contrast, clinical studies have consistently shown that the two drugs have no activity in absence epilepsy [64, 65], and gabapentin can precipitate absence and myoclonic status epilepticus [66-68]. This paradoxical aggravation, that usually results in subtle or overt increased seizure activity and worsening of EEG abnormalities, is increasingly recognized as a serious and common problem [67]. Moreover, clinical and EEG pitfalls in the diagnosis of epilepsy may often result in erroneous classification and treatment choices. In animal studies, pregabalin did not affect the incidence of SWDs in GAERS [69] and gabapentin had no effect on absence-like seizures in the lethargic mouse model of human absence epilepsy [70].

\section{POTENTIAL EXPLANATIONS FOR THE AMBIGUOUS ROLE OF THE $\alpha_{2} \delta$ SUBUNIT IN ABSENCE EPILEPSY}

\subsection{Modulation of Non-T-type VSCCs}

One possible explanation for the epileptic phenotype of ducky and entla mice is that the loss of $\alpha_{2} \delta$ subunit causes 
absence seizures by restraining the activity of $\mathrm{HVA} \mathrm{Ca}^{2+}$ channels (P/Q, N, L and R channels). Although $\mathrm{T}$ channels are one of the major players in the generation of pathological oscillations in the cortico-thalamo-cortical network, a large body of evidence suggests that HVA channels are also involved in the pathophysiology of absence seizures. Pharmacological activation of L-type $\mathrm{HVA} \mathrm{Ca}{ }^{2+}$ channels alters the firing rate of thalamocortical neurons [71], and systemic administration of L-type $\mathrm{Ca}^{2+}$ channel blocker, nimodipine, increases the frequency of SWDs. In contrast, a decreased incidence of SWDs was found after intracerebroventricular injection of the L-type $\mathrm{Ca}^{2+}$ channel opener, BAY K8644, which could also antagonise the effects of nimodipine on SWDs $[72,73]$. R-type channels are also involved in the generation of oscillatory burst discharges in nRT neurons [74], and administration of the selective R-type $\mathrm{Ca}^{2+}$ blocker, conotoxin GVIA, reduces SWDs [73]. The Ntype $\mathrm{Ca}^{2+}$ channel blocker, $\omega$-conotoxin MVIIA, can also reduce the number of SWDs [75]. Mutations of the Cacnala gene encoding for the $\alpha_{1}$ subunit of P/Q-type $\mathrm{Ca}^{2+}$ channels are associated with absence seizures in rodents and humans [76-78]. Genetic deletion of the Cacnala gene in cortical layer VI neurons enhances T-type $\mathrm{Ca}^{2+}$ currents in thalamic relay and $\mathrm{nRT}$ neurons, thereby generating synchronous SWDs that are inhibited by ethosuximide [79]. It is possible that in ducky mice a reduced expression/activity of HVA VSCCs generates absence seizures either directly or as a result of a compensatory increase in the activity of T-type calcium channels.

\subsection{Beyond VSCCs: The $\alpha_{2} \delta$ Subunit Mediates the Action of Thrombospondins in the CNS}

\subsubsection{Physiology of Thrombospondins in the CNS}

The $\alpha_{2} \delta$ subunit is the receptor for a class of proteins, called thrombospondins (TSPs), which were first isolated from platelets stimulated with thrombin and show a widespread distribution in various organs, including the CNS. TSPs are a large oligomeric extracellular matrix (ECM) proteins, found in vertebrates and lower metazoa [80-82]. The human TSP protein family consists of five members (TSP-1, TSP-2, TSP-3, TSP-4, and TSP-5, or COMP, cartilage oligomeric matrix protein) which are subdivided into two groups [80, $83,84]$ on the basis of their oligomerization state and domain structure. Subgroup A includes TSP-1 and TSP-2, which form homotrimers; subgroup B includes TSP-3, TSP4, and TSP-5, which form homopentamers [85]. The various isoforms of TSPs are the products of different genes, and display differential non-overlapping functions [86].

TSPs primarily regulate cell-cell and cell-extracellular matrix interactions [87] acting through a number of ECM proteins and cell surface receptors and controlling cytoskeletal dynamics, cell migration, and cell attachment [88]. All these activities regulate many aspects of cell phenotype and contribute to angiogenesis and wound healing, vessel wall biology and synaptogenesis [84].

Astrocyte-secreted TSP-1, TSP-2 promote synaptogenesis in cultured hippocampal neurons [89] and retinal ganglion cells [90], and TSP-1 can also promote neuronal migration [91] and axonal growth [92]. TSP-1 and TSP-2 are highly expressed during development [89, 90, 93] and acts in specific time windows to promote synaptogenesis in the developing brain. TSP-4 is exclusively expressed by mature astrocytes, and represents the mature TSP isoform in the CNS [88].

Eroglu et al. [94] have shown for the first time that the synaptogenic epidermal growth factor (EGF)-like repeat domains of TSPs interact with the VWF-A (von Willebrand factor) domain of $\alpha_{2} \delta-1$. This interaction mediates the synaptogenic activity of TSPs. Accordingly, overexpression of $\alpha_{2} \delta-1$ enhanced synaptogenesis in mice, and the $\alpha_{2} \delta$ ligand, gabapentin, restrained the synaptogenic activity of TSPs [94].

\subsubsection{Potential Role for Thrombospondins in the Pathophysiology of Absence Epilepsy}

A potential link between alterations in synaptogenesis and absence epilepsy is suggested by the evidence that stargazin mutation in mice causes an impairment in synaptic formation and maturation in the cerebellum [95]. In addition, double mutant $z i / z i, \mathrm{tm} / \mathrm{tm}$ rats, which spontaneously develop absence seizures after 6 weeks of age, show a low expression of the synaptic vesicle proteins, SV2A and synaptotagmin-1 [96]. We have found a selective reduction of the transcript encoding for TSP-1 in the ventrobasal thalamus of presymptomatic and symptomatic WAG/Rij rats [97], which model human absence epilepsy [98, 99].

An attractive hypothesis is that the TSP $/ \alpha_{2} \delta$ axis plays a key role in synaptic formation within the cortico-thalamocortical network that lies at the core of the pathophysiology of absence epilepsy [3] and that defects in either TSPs or $\alpha_{2} \delta$ disrupt synaptic organization in the circuit resulting into absence seizures. TSPs may have a broader role in epileptogenesis that involves other types of epilepsy. Mendus et al. [100] have recently found that mice with genetic deletion of TSP-1 show an increased sensitivity to chemical kindling induced by repeated administrations of a subconvulsive dose of pentylenetetrazole (PTZ). TSP-1 knockout mice developed generalized tonic-clonic seizures in response to the second administration of PTZ, whereas at least eight administrations were required to produce the same phenotype in wild-type mice [100]. Interestingly, TSP-1 knockout mice also showed a reduced expression of both $\alpha_{2} \delta-1$ and $\alpha_{2} \delta-2$ subunits in the frontal cortex [100].

In conclusion, the $\alpha_{2} \delta$ subunit subserves pleiotropic functions that may be relevant for the pathophysiology of different type of epilepsy including absence epilepsy and may be targeted by therapeutic intervention. The role of $\alpha_{2} \delta$ subunit in absence epilepsy cannot be reconducted to the modulation of T-type channels, and may involve other types of VSCCs. In addition, increasing evidence suggests that the $\mathrm{TSP} / \alpha_{2} \delta$ axis can be dysfunctional in absence epilepsy and other forms of epilepsy (Fig. 2). Abnormalities in either TSPs and/or $\alpha_{2} \delta$ subunit may contribute to the process of epileptogenesis, which is ultimately responsible for the recurrence of epileptic seizures. If proven to be correct, this may lay the groundwork for the design of novel disease modifying drugs that are directed towards mechanisms that lie at the core of epileptogenesis. 


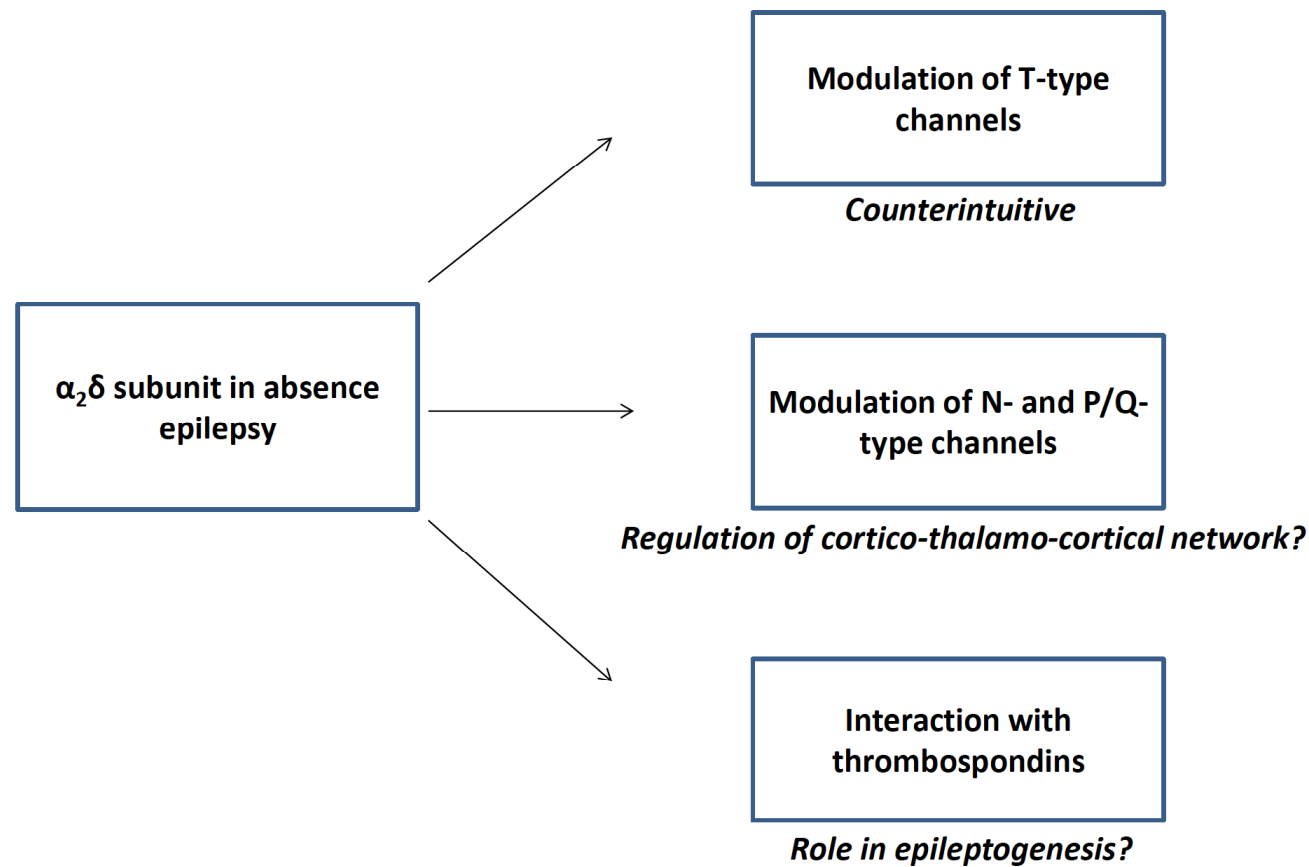

Fig. (2). Potential mechanisms explaining why genetic deletion or pharmacological inhibition of the $\alpha_{2} \delta$ subunit facilitates the generation of absence seizures.

\section{CONFLICT OF INTEREST}

The authors declare no conflict of interest, financial or otherwise.

\section{ACKNOWLEDGEMENTS}

Declared none.

\section{REFERENCES}

[1] Panayiotopoulos, C.P. Typical absence seizures and related epileptic syndromes: assessment of current state and directions for future research. Epilepsia, 2008, 49, 2131-2138.

[2] Engel, J., Jr. ILAE classification of epilepsy syndromes. Epilepsy Res., 2006, 70(Suppl. 1), S5-S10.

[3] Blumenfeld, H. Cellular and network mechanisms of spike-wave seizures. Epilepsia, 2005, 46(Suppl. 9), 21-33.

[4] Avoli, M.; Gloor, P. Interaction of cortex and thalamus in spike and wave discharges of feline generalized penicillin epilepsy. Exp. Neurol., 1982, 76(1), 196-217.

[5] Meeren, H.; van Luijtelaar, G.; Lopes da Silva, F.; Coenen, A. Evolving concepts on the pathophysiology of absence seizures: the cortical focus theory. Arch. Neurol., 2005, 62(3), 371-376.

[6] van Luijtelaar, G.; Sitnikova, E.; Littjohann, A. On the origin and suddenness of absences in genetic absence models. Clin. EEG Neurosci., 2011, 42(2), 83-97.

[7] Ngomba, R.T.; Santolini, I.; Salt, T.E.; Ferraguti, F.; Battaglia, G.; Nicoletti, F.; van Luijtelaar, G. Metabotropic glutamate receptors in the thalamocortical network: strategic targets for the treatment of absence epilepsy. Epilepsia, 2011, 52(7), 1211-1222.

[8] Kohmann, D.; Lüttjohann, A.; Seidenbecher, T.; Coulon, P.; Pape, H.C. Short-term depression of gap junctional coupling in reticular thalamic neurons of absence epileptic rats. J. Physiol., 2016, 594(19), 5695-5710.

[9] Meldrum, B.S.; Rogawski, M.A. Molecular targets for antiepileptic drug development. Neurotherapeutics, 2007, 4(1), 18-61.

[10] Sun, Y.G.; Wu, C.S.; Renger, J.J.; Uebele, V.N.; Lu, H.C.; Beierlein, M. GABAergic synaptic transmission triggers action potentials in thalamic reticular nucleus neurons. $J$. Neurosci., 2012 32(23), 7782-7790

[11] Perez-Reyes, E. Molecular characterization of T-type calcium channels. Cell Calcium, 2006, 40(2), 89-96.

[12] Talavera, K.; Nilius, B. Biophysics and structure-function relationship of T-type $\mathrm{Ca}^{2+}$ channels. Cell Calcium, 2006, 40(2), 97-114.

[13] Coulter, D.A.; Huguenard, J.R.; Prince, D.A. Characterization of ethosuximide reduction of low-threshold calcium current in thalamic neurons. Ann. Neurol., 1989, 25(6), 582-593.

[14] Crunelli, V.; Leresche, N. Block of Thalamic T-Type $\mathrm{Ca}^{(2+)}$ Channels by ethosuximide is not the whole story. Epilepsy Curr., 2002, 2(2), 53-56. [https://doi.org/10.1046/j.1535-7597.2002.00024.x]

[15] Manning, J.P.; Richards, D.A.; Leresche, N.; Crunelli, V.; Bowery, N.G. Cortical-area specific block of genetically determined absence seizures by ethosuximide. Neuroscience, 2004, 123(1), 5-9. [https://doi.org/10.1016/j.neuroscience.2003.09.026]

[16] Catterall, W.A.; Perez-Reyes, E.; Snutch, T.P.; Striessnig, J. International Union of Pharmacology. XLVIII. Nomenclature and structure-function relationships of voltage-gated calcium channels. Pharmacol. Rev., 2005, 57(4), 411-425. [https://doi.org/10.1124/pr. 57.4.5]

[17] Ernst, W.L.; Zhang, Y.; Yoo, J.W.; Ernst, S.J.; Noebels, J.L. Genetic enhancement of thalamocortical network activity by elevating alpha $1 \mathrm{~g}$-mediated low-voltage-activated calcium current induces pure absence epilepsy. J. Neurosci., 2009, 29(6), 16151625. [https://doi.org/10.1523/JNEUROSCI.2081-08.2009]

[18] Cain, S.M.; Snutch, T.P. Contributions of T-type calcium channel isoforms to neuronal firing. Channels (Austin), 2010, 4(6), 475482. [https://doi.org/10.4161/chan.4.6.14106]

[19] Cheong, E.; Shin, H.S. T-type $\mathrm{Ca}^{2+}$ channels in absence epilepsy. Biochim. Biophys. Acta, 2013, 1828(7), 1560-1571.

[20] Broicher, T.; Kanyshkova, T.; Meuth, P.; Pape, H.C.; Budde, T. Correlation of T-channel coding gene expression, IT, and the low threshold $\mathrm{Ca}^{2+}$ spike in the thalamus of a rat model of absence epilepsy. Mol. Cell. Neurosci., 2008, 39(3), 384-399.

[21] Sharopa, B.S.; Boldyrieva, O.I.; Batiukb, M.Y.; Shtefana, N.L.; Shubaa, Y.M. Compensatory reduction of Cav3.1 expression in thalamocortical neurons of juvenile rats of WAG/Rij model of absence epilepsy. Epilepsy Res., 2016, 119, 10-12. 
[22] Catterall, W.A. Structure and regulation of voltage-gated $\mathrm{Ca}^{2+}$ channels. Annu. Rev. Cell Dev. Biol., 2000, 16, 521-555.

[23] Buraei, Z.; Yang, J. Structure and function of the $\beta$ subunit of voltage-gated $\mathrm{Ca}^{2+}$ channels. Biochim. Biophys. Acta, 2013, 1828 (7), 1530-1540.

[24] Chen, R.S.; Deng, T.C.; Garcia, T.; Sellers, Z.M.; Best, P.M. Calcium channel gamma subunits: a functionally diverse protein family. Cell Biochem. Biophys., 2007, 47(2), 178-186.

[25] Tomita, S.; Shenoy, A.; Fukata, Y.; Nicoll, R.A.; Bredt, D.S. Stargazin interacts functionally with the AMPA receptor glutamatebinding module. Neuropharmacology, 2007, 52(1), 87-91.

[26] Kato, A.S.; Gill, M.B.; Yu, H.; Nisenbaum, E.S.; Bredt, D.S. TARPs differentially decorate AMPA receptors to specify neuropharmacology. Trends Neurosci., 2010, 33(5), 241-248.

[27] Chen, L.; Chetkovich, D.M.; Petralia, R.S.; Sweeney, N.T.; Kawasaki, Y.; Wenthold, R.J.; Bredt, D.S.; Nicoll, R.A. Stargazin regulates synaptic targeting of AMPA receptors by two distinct mechanisms. Nature, 2000, 408(6815), 936-943.

[28] Coombs, I.D.; Cull-Candy, S.G. Transmembrane AMPA receptor regulatory proteins and AMPA receptor function in the cerebellum. Neuroscience, 2009, 162(3), 656-665.

[29] Menuz, K.; Nicoll, R.A. Loss of inhibitory neuron AMPA receptors contributes to ataxia and epilepsy in stargazer mice. J. Neurosci., 2008, 28(42), 10599-10603.

[30] Payne, H.L. The role of transmembrane AMPA receptor regulatory proteins (TARPs) in neurotransmission and receptor trafficking. Mol. Membr. Biol., 2008, 25(4), 353-362.

[31] Kennard, J.T.; Barmanray, R.; Sampurno, S.; Ozturk, E.; Reid, C.A.; Paradiso, L.; D'Abaco, G.M.; Kaye, A.H.; Foote, S.J.; O'Brien, T.J.; Powell, K.L. Stargazin and AMPA receptor membrane expression is increased in the somatosensory cortex of genetic absence epilepsy rats from strasbourg. Neurobiol. Dis., 2011, 42(1), 48-54.

[32] De Jongh, K.S.; Warner, C.; Catterall, W.A. Subunits of purified calcium channels. Alpha 2 and delta are encoded by the same gene. J. Biol. Chem., 1990, 265(25), 14738-14741.

[33] Cole, R.L.; Lechner, S.M.; Williams, M.E.; Prodanovich, P.; Bleicher, L.; Varney, M.A.; Gu, G. Differential distribution of voltage-gated calcium channel alpha-2 delta (alpha2delta) subunit mRNA-containing cells in the rat central nervous system and the dorsal root ganglia. J. Comp. Neurol., 2005, 491(3), 246-269.

[34] Barclay, J.; Balaguero, N.; Mione, M.; Ackerman, S.L.; Letts, V.A.; Brodbeck, J.; Canti, C.; Meir, A.; Page, K.M.; Kusumi, K.; Perez-Reyes, E.; Lander, E.S.; Frankel, W.N.; Gardiner, R.M.; Dolphin, A.C.; Rees, M. Ducky mouse phenotype of epilepsy and ataxia is associated with mutations in the Cacna2d2 gene and decreased calcium channel current in cerebellar Purkinje cells. $J$. Neurosci., 2001, 21(16), 6095-6104.

[35] Arikkath, J.; Campbell, K.P. Auxiliary subunits: essential components of the voltage-gated calcium channel complex. Curr. Opin. Neurobiol., 2003, 13(3), 298-307.

[36] Dolphin, A.C. G protein modulation of voltage-gated calcium channels. Pharmacol. Rev., 2003, 55(4), 607-627.

[37] Cantí, C.; Nieto-Rostro, M.; Foucault, I.; Heblich, F.; Wratten, J.; Richards, M.W.; Hendrich, J.; Douglas, L.; Page, K.M.; Davies, A.; Dolphin, A.C. The metal-ion-dependent adhesion site in the Von Willebrand factor-A domain of alpha2delta subunits is key to trafficking voltage-gated $\mathrm{Ca}^{2+}$ channels. Proc. Natl. Acad. Sci. USA, 2005, 102(32), 11230-11235.

[38] Hendrich, J.; Van Minh, A.T.; Heblich, F.; Nieto-Rostro, M.; Watschinger, K.; Striessnig, J.; Wratten, J.; Davies, A.; Dolphin, A.C. Pharmacological disruption of calcium channel trafficking by the alpha2delta ligand gabapentin. Proc. Natl. Acad. Sci. USA, 2008, 105(9), 3628-3633.

[39] Davies, A.; Kadurin, I.; Alvarez-Laviada, A.; Douglas, L.; NietoRostro, M.; Bauer, C.S.; Pratt, W.S.; Dolphin, A.C. The alpha2delta subunits of voltage-gated calcium channels form GPIanchored proteins, a posttranslational modification essential for function. Proc. Natl. Acad. Sci. USA, 2010, 107(4), 1654-1659.
[40] Hoppa, M.B.; Lana, B.; Margas, W.; Dolphin, A.C.; Ryan, T.A. $\alpha_{2} \delta$ expression sets presynaptic calcium channel abundance and release probability. Nature, 2012, 486(7401), 122-125.

[41] Bauer, C.S.; Nieto-Rostro, M.; Rahman, W.; Tran-Van-Minh, A.; Ferron, L.; Douglas, L.; Kadurin, I.; Sri Ranjan, Y.; FernandezAlacid, L.; Millar, N.S.; Dickenson, A.H.; Lujan, R.; Dolphin, A.C. The increased trafficking of the calcium channel subunit alpha2delta-1 to presynaptic terminals in neuropathic pain is inhibited by the alpha2delta ligand pregabalin. J. Neurosci., 2009, 29(13), 4076-4088.

[42] Wyatt, C.N.; Page, K.M.; Berrow, N.S.; Brice, N.L.; Dolphin, A.C. The effect of overexpression of auxiliary $\mathrm{Ca}^{2+}$ channel subunits on native $\mathrm{Ca}^{2+}$ channel currents in undifferentiated mammalian NG108-15cells. J. Physiol., 1998, 510(Pt 2), 347-360.

[43] Dolphin, A.C.; Wyatt, C.N.; Richards, J.; Beattie, R.E.; Craig, P.; Lee, J.H.; Cribbs, L.L.; Volsen, S.G.; Perez-Reyes, E. The effect of alpha2-delta and other accessory subunits on expression and properties of the calcium channel alpha1G. J. Physiol., 1999, 519(Pt 1), 35-45.

[44] Dubel, S.J.; Altier, C.; Chaumont, S.; Lory, P.; Bourinet, E.; Nargeot, J. Plasma membrane expression of T-type calcium channel alpha(1) subunits is modulated by high voltage-activated auxiliary subunits. J. Biol. Chem., 2004, 279(28), 29263-29269.

[45] Thompson, W.R.; Majid, A.S.; Czymmek, K.J.; Ruff, A.L.; García, J.; Duncan, R.L.; Farach-Carson, M.C. Association of the $\alpha(2) \delta(1)$ subunit with $\mathrm{Ca}(\mathrm{v}) 3.2$ enhances membrane expression and regulates mechanically induced ATP release in MLO-Y4 osteocytes. J. Bone Miner. Res., 2011, 26(9), 2125-2139.

[46] Hobom, M.; Dai, S.; Marais, E.; Lacinova, L.; Hofmann, F.; Klugbauer, N. Neuronal distribution and functional characterization of the calcium channel alpha2delta-2 subunit. Eur. J. Neurosci., 2000, 12(4), 1217-1226.

[47] Lacinová, L.; Klugbauer, N. Modulation of gating currents of the $\mathrm{Ca}(\mathrm{v}) 3.1$ calcium channel by alpha 2 delta 2 and gamma 5 subunits. Arch. Biochem. Biophys., 2004, 425(2), 207-213.

[48] Lacinová, L.; Klugbauer, N.; Hofmann, F. Absence of modulation of the expressed calcium channel alpha $1 \mathrm{G}$ subunit by alpha2delta subunits. J. Physiol., 1999, 516(Pt 3), 639-645.

[49] Chioza, B.A.; Aicardi, J.; Aschauer, H.; Brouwer, O.; Callenbach, P.; Covanis, A.; Dooley, J.M.; Dulac, O.; Durner, M.; EegOlofsson, O.; Feucht, M.; Friis, M.L.; Guerrini, R.; Kjeldsen, M.J.; Nabbout, R.; Nashef, L.; Sander, T.; Sirén, A.; Wirrell, E.; McKeigue, P.; Robinson, R.; Gardiner, R.M.; Everett, K.V. Genome wide high density SNP-based linkage analysis of childhood absence epilepsy identifies a susceptibility locus on chromosome 3p23-p14. Epilepsy Res., 2009, 87(2-3), 247-255.

[50] Meier, H. The neuropathology of ducky, a neurological mutation of the mouse. A pathological and preliminary histochemical study. Acta Neuropathol., 1968, 11(1), 15-28.

[51] Brill, J.; Klocke, R.; Paul, D.; Boison, D.; Gouder, N.; Klugbauer, N.; Hofmann, F.; Becker, C.M.; Becker, K. entla, a novel epileptic and ataxic Cacna2d 2 mutant of the mouse. J. Biol. Chem., 2004, 279, 7322-7330.

[52] Ivanov, S.V.; Ward, J.M.; Tessarollo, L.; McAreavey, D.; Sachdev, V.; Fananapazir, L.; Banks, M.K.; Morris, N.; Djurickovic, D.; Devor-Henneman, D.E.; Wei, M.H.; Alvord, G.W.; Gao, B.; Richardson, J.A.; Minna, J.D.; Rogawski, M.A.; Lerman, M.I. Cerebellar ataxia, seizures, premature death, and cardiac abnormalities in mice with targeted disruption of the Cacna $2 \mathrm{~d} 2$ gene. Am. J. Pathol., 2004, 165, 1007-1018.

[53] Bialer, M. Why are antiepileptic drugs used for nonepileptic conditions? Epilepsia, 2012, 53(Suppl. 7), 26-33.

[54] Johannessen, L.C. Antiepileptic drugs in non-epilepsy disorders: relations between mechanisms of action and clinical efficacy. CNS Drugs, 2008, 22(1), 27-47.

[55] Cantí, C.; Davies, A.; Dolphin, A.C. Calcium channel $\alpha_{2} \delta$ subunits: Structure, functions and target site for drugs. Curr. Neuropharmacol., 2003, 1(3), 209-217.

[56] Klugbauer, N.; Marais, E.; Hofmann, F. Calcium channel alpha2delta subunits: differential expression, function, and drug binding. J. Bioenerg. Biomembr., 2003, 35(6), 639-647. 
[57] Davies, A.; Hendrich, J.; Van Minh, A.T.; Wratten, J.; Douglas, L.; Dolphin, A.C. Functional biology of the alpha(2)delta subunits of voltage-gated calcium channels. Trends Pharmacol. Sci., 2007, 28(5), 220-228.

[58] Lana, B.; Schlick, B.; Martin, S.; Pratt, W.S.; Page, K.M.; Goncalves, L.; Rahman, W.; Dickenson, A.H.; Bauer, C.S.; Dolphin, A.C. Differential upregulation in DRG neurons of an $\alpha_{2} \delta$ 1 splice variant with a lower affinity for gabapentin after peripheral sensory nerve injury. Pain, 2014, 155(3), 522-533.

[59] Gee, N.S.; Brown, J.P.; Dissanayake, V.U.; Offord, J.; Thurlow, R.; Woodruff, G.N. The novel anticonvulsant drug, gabapentin (Neurontin), binds to the alpha2delta subunit of a calcium channel. J. Biol. Chem., 1996, 271(10), 5768-5776.

[60] Gong, H.C.; Hang, J.; Kohler, W.; Li, L.; Su, T.Z. Tissue-specific expression and gabapentin-binding properties of calcium channel alpha2delta subunit subtypes. J. Membr. Biol., 2001, 184(1), 35-43.

[61] Dooley, D.J.; Taylor, C.P.; Donevan, S.; Feltner, D. $\mathrm{Ca}^{2+}$ channel alpha2delta ligands: novel modulators of neurotransmission. Trends Pharmacol. Sci., 2007, 28(2), 75-82.

[62] Dolphin, A.C. Calcium channel auxiliary $\alpha_{2} \delta$ and $\beta$ subunits: trafficking and one step beyond. Nat. Rev. Neurosci., 2012, 13(8), 542-555.

[63] Stahl, S.M.; Porreca, F.; Taylor, C.P.; Cheung, R.; Thorpe, A.J.; Clair, A. The diverse therapeutic actions of pregabalin: is a single mechanism responsible for several pharmacological activities? Trends Pharmacol. Sci., 2013, 34(6), 332-339.

[64] Trudeau, V.; Myers, S.; LaMoreaux, L.; Anhut, H.; Garofalo, E.; Ebersole, J. Gabapentin in naïve childhood absence epilepsy: results from two double-blind, placebo-controlled, multicenter studies. J. Child Neurol., 1996, 11(6), 470-475.

[65] Chadwick, D.; Leiderman, D.B.; Sauermann, W.; Alexander, J.; Garofalo, E. Gabapentin in generalized seizures. Epilepsy Res., 1996, 25(3), 191-197.

[66] Perucca, E.; Gram, L.; Avanzini, G.; Dulac, O. Antiepileptic drugs as a cause of worsening seizures. Epilepsia, 1998, 39(1), 5-17.

[67] Thomas, P.; Valton, L.; Genton, P. Absence and myoclonic status epilepticus precipitated by antiepileptic drugs in idiopathic generalized epilepsy. Brain, 2006, 129(Pt 5), 1281-1292.

[68] Striano, P.; Coppola, A.; Madia, F.; Pezzella, M.; Ciampa, C.; Zara, F.; Striano, S. Life-threatening status epilepticus following gabapentin administration in a patient with benign adult familial myoclonic epilepsy. Epilepsia, 2007, 48(10), 1995-1998.

[69] Vartanian, M.G.; Radulovic, L.L.; Kinsora, J.J.; Serpa, K.A.; Vergnes, M.; Bertram, E.; Taylor, C.P. Activity profile of pregabalin in rodent models of epilepsy and ataxia. Epilepsy Res., 2006, 68(3), 189-205.

[70] Hosford, D.A.; Wang, Y. Utility of the lethargic (lh/lh) mouse model of absence seizures in predicting the effects of lamotrigine, vigabatrin, tiagabine, gabapentin, and topiramate against human absence seizures. Epilepsia, 1997, 38(4), 408-414.

[71] Kanyshkova, T.; Ehling, P.; Cerina, M.; Meuth, P.; Zobeiri, M.; Meuth, S.G.; Pape, H.C.; Budde, T. Regionally specific expression of high-voltage-activated calcium channels in thalamic nuclei of epileptic and non-epileptic rats. Mol. Cell. Neurosci., 2014, 61, 110-122. https://doi.org/10.1016/j.mcn.2014.06.005

[72] van Luijtelaar, E.L.; Ates, N.; Coenen, A.M. Role of L-type calcium channel modulation in nonconvulsive epilepsy in rats. Epilepsia, 1995, 36(1), 86-92. [https://doi.org/10.1111/j.15281157.1995.tb01671.x]

[73] van Luijtelaar, G.; Wiaderna, D.; Elants, C.; Scheenen, W. Opposite effects of $\mathrm{T}$ - and L-type $\mathrm{Ca}^{(2+)}$ channels blockers in generalized absence epilepsy. Eur. J. Pharmacol., 2000, 406(3), 381-389. [https://doi.org/10.1016/S0014-2999(00)00714-7]

[74] Zaman, T.; Lee, K.; Park, C.; Paydar, A.; Choi, J.H.; Cheong, E.; Lee, C.J.; Shin, H.S. Cav2.3 channels are critical for oscillatory burst discharges in the reticular thalamus and absence epilepsy. Neuron, 2011, 70(1), 95-108. [https://doi.org/10.1016/j.neuron.2011. 02.042]

[75] Durmus, N.; Gültürk, S.; Kaya, T.; Demir, T.; Parlak, M.; Altun, A. Evaluation of effects of $\mathrm{T}$ and $\mathrm{N}$ type calcium channel blockers on the electroencephalogram recordings in Wistar Albino Glaxo/Rij rats, an absence epilepsy model. Ind. J. Indian. J. Pharmacol., 2015, 47(1), 34-38.

[76] Burgess, D.L.; Noebels, J.L. Single gene defects in mice: the role of voltage-dependent calcium channels in absence models. Epilepsy Res., 1999, 36(2-3), 111-122.

[77] Zamponi, G.W.; Lory, P.; Perez-Reyes, E. Role of voltage-gated calcium channels in epilepsy. Pflugers Arch., 2010, 460(2), 395 403.

[78] Serikawa, T.; Mashimo, T.; Kuramoro, T.; Voigt, B.; Ohno, Y.; Sasa, M. Advances on genetic rat models of epilepsy. Exp. Anim., 2015, 64(1), 1-7.

[79] Bomben, V.C.; Aiba, I.; Qian, J.; Mark, M.D.; Herlitze, S.; Jeffrey, L.N. Isolated P/Q Calcium Channel Deletion in Layer VI Corticothalamic neurons generates absence epilepsy. J. Neurosci., 2016, 36(2), 405-418.

[80] Adams, J.C. Thrombospondins: multifunctional regulators of cell interactions. Annu. Rev. Cell Dev. Biol., 2001, 17, 25-51.

[81] Bentley, A.A.; Adams, J.C. The evolution of thrombospondins and their ligand-binding activities. Mol. Biol. Evol., 2010, 27(9), $2187-$ 2197.

[82] Mosher, D.F.; Adams, J.C. Adhesion-modulating/matricellular ECM protein families: a structural, functional and evolutionary appraisal. Matrix Biol., 2012, 31(3), 155-161.

[83] Adams, J.C.; Lawler, J. The thrombospondins. Int. J. Biochem. Cell Biol., 2004, 36, 961-968. [https://doi.org/10.1016/j.biocel.2004.01. 004]

[84] Adams, J.C.; Lawler, J. The thrombospondins. Cold Spring Harb. Perspect. Biol., 2011, 3(10), a009712.

[85] Lawler, J. Thrombospondin-1 as an endogenous inhibitor of angiogenesis and tumor growth. J. Cell. Mol. Med., 2002, 6, 1-12.

[86] Stenina-Adognravi, O. Thrombospondins: old players, new games. Curr. Opin. Lipidol., 2013, 24(5), 401-409.

[87] Bornstein, P. Matricellular proteins: an overview. Matrix Biol. 2000, 19(7), 555-556.

[88] Bornstein, P.; Agah, A.; Kyriakides, T.R. The role of thrombospondins 1 and 2 in the regulation of cellmatrix interactions, collagen fibril formation, and the response to injury. Int. J. Biochem. Cell Biol., 2004, 36, 1115-1125.

[89] Xu, J.; Xiao, N.; Xia, J. Thrombospondin 1 accelerates synaptogenesis in hippocampal neurons through neuroligin 1. Nat. Neurosci., 2010, 13(1), 22-24.

[90] Christopherson, K.S.; Ullian, E.M.; Stokes, C.C.; Mullowney, C.E.; Hell, J.W.; Agah, A.; Lawler, J.; Mosher, D.F.; Bornstein, P.; Barres, B.A. Thrombospondins are astrocyte-secreted proteins that promote CNS synaptogenesis. Cell, 2005, 120(3), 421-433.

[91] Iruela-Arispe, M.L.; Liska, D.J.; Sage, E.H.; Bornstein, P. Differential expression of thrombospondin 1, 2, and 3 during murine development. Dev. Dyn., 1993, 197(1), 40-56.

[92] Yu, K.; Ge, J.; Summers, J.B.; Li, F.; Liu, X.; Ma, P.; Kaminski, J.; Zhuang, J. TSP-1 secreted by bone marrow stromal cells contributes to retinal ganglion cell neurite outgrowth and survival. PLoS One, 2008, 3(6), e2470. [https://doi.org/10.1371/journal. pone.0002470]

[93] Cahoy, J.D.; Emery, B.; Kaushal, A.; Foo, L.C.; Zamanian, J.L.; Christopherson, K.S.; Xing, Y.; Lubischer, J.L.; Krieg, P.A.; Krupenko, S.A.; Thompson, W.J.; Barres, B.A. A transcriptome database for astrocytes, neurons, and oligodendrocytes: a new resource for understanding brain development and function. J. Neurosci., 2008, 28(1), 264-278. [https://doi.org/10.1523/ JNEUROSCI.4178-07.2008]

[94] Eroglu, C.; Allen, N.J.; Susman, M.W.; O'Rourke, N.A.; Park, C.Y.; Ozkan, E.; Chakraborty, C.; Mulinyawe, S.B.; Annis, D.S.; Huberman, A.D.; Green, E.M.; Lawler, J.; Dolmetsch, R.; Garcia, K.C.; Smith, S.J.; Luo, Z.D.; Rosenthal, A.; Mosher, D.F.; Barres, B.A. Gabapentin receptor alpha2delta-1 is a neuronal thrombospondin receptor responsible for excitatory CNS synaptogenesis. Cell, 2009, 139(2), 380-392. [https://doi.org/10. 1016/j.cell.2009.09.025]

[95] Meng, H.; Walker, N.; Su, Y.; Qiao, X. Stargazin mutation impairs cerebellar synaptogenesis, synaptic maturation and synaptic protein 
distribution. Brain Res., 2006, 1124(1), 197-207. [https://doi.org/ 10.1016/j.brainres.2006.09.086]

[96] Hanaya, R.; Hosoyama, H.; Sugata, S.; Tokudome, M.; Hirano, H.; Tokimura, H.; Kurisu, K.; Serikawa, T.; Sasa, M.; Arita, K. Low distribution of synaptic vesicle protein $2 \mathrm{~A}$ and synaptotagimin-1 in the cerebral cortex and hippocampus of spontaneously epileptic rats exhibiting both tonic convulsion and absence seizure. Neuroscience, 2012, 221, 12-20. [https://doi.org/10.1016/j.neuroscience. 2012.06.058]

[97] Santolini, I.; Guiducci, M.; Imbriglio, T.; Celli, R.; Cannella, M.; Motolese, M.; D’Amore, V.; Gradini, R.; van Luijtelaar, G.; Parisi, P.; Nicoletti, F.; Striano, P.; Ngomba, R.T. Reduced thalamic expression of thrombospondin-1 in a rat model of spontaneous absence epilepsy, 2015.

[98] van Luijtelaar, E.L.; Coenen, A.M. Two types of electrocortical paroxysms in an inbred strain of rats. Neurosci. Lett., 1986, 70(3), 393-397. [https://doi.org/10.1016/0304-3940(86)90586-0]

[99] van Luijtelaar, E.L.; Coenen, A.M. The WAG/Rij rat model of absence epilepsy: ten years of research; Nijmegen University Press: Nijmegen, 1997.

[100] Mendus, D.; Rankin-Gee, E.K.; Mustapha, M.; Porter, B.E. Increased sensitivity to kindling in mice lacking TSP1. Neuroscience, 2015 , 305, 302-308. [https://doi.org/10.1016/j.neuroscience.2015.07.075] 